Original Research Paper

\title{
Ecobrick Sebagai Solusi Penanggulangan Sampah Non-Organik Rumah Tangga di Lingkungan Sayo Baru
}

\author{
Wisnu Pratama Nuruzzaman', Marianti², Agisniati Zain ${ }^{3}$, Desi Rosmaya Putri ${ }^{4}$, Mitha Amara ${ }^{5}$, I Made \\ Sukerta $^{6}$, Vira Heryanto ${ }^{7}$, Putri Jauhar Prihatini ${ }^{8}$, Rr. Devi Delima Swiswidayati', Joni Rokhmat ${ }^{10^{*}}$

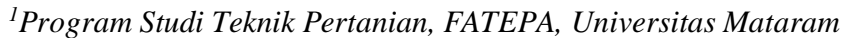 \\ ${ }^{2}$ Program Studi Agroekoteknologi, Fakultas Pertanian, Universitas Mataram \\ ${ }^{3}$ Program Studi Agroekoteknologi, Fakultas Pertanian, Universitas Mataram \\ ${ }^{4}$ Program Studi Agroekoteknologi, Fakultas Pertanian, Universitas Mataram \\ ${ }^{5}$ Program Teknik Informatika, Fakultas Teknik, Universitas Mataram \\ ${ }^{6}$ Program Studi Teknik Sipil, Fakultas Teknik, Universitas Mataram \\ ${ }^{7}$ Program Studi Biologi, Fakultas MIPA, Universitas Mataram \\ ${ }^{8}$ Program Studi Kimia, Fakultas MIPA, Universitas Mataram \\ ${ }^{9}$ Program Studi Fisika, Fakultas MIPA, Universitas Mataram \\ ${ }^{10}$ Program Studi Pendidikan Fisika, FPMIPA, Universitas Mataram
}

DOI: https://doi.org/10.29303/jpmpi.v4i2.732

Sitasi: Nuruzzaman, W. P., Marianti., Zain, A., Putri, D. R., Amara, M., Sukerta, I. M., Heryanto, V., Prihatini, P. J., Swiswidayati, R. D. D., \& Rokhmat, J. (2021). Ecobrick Sebagai Solusi Penanggulangan Sampah Non-Organik Rumah Tangga di Lingkungan Sayo Baru. Jurnal Pengabdian Magister Pendidikan IPA, 4(2)

\author{
Article history \\ Received: 03 Maret 2021 \\ Revised: 03 April 2021 \\ Accepted: 24 Mei 2021 \\ *Corresponding Author: Joni \\ Rokhmat, Program Studi \\ Pendidikan Fisika, FPMIPA, \\ Universitas Mataram; \\ Email: joni.fkip@unram.ac.id
}

Abstract: Tujuan dari diadakannnya program kerja "Ecobrick" ini adalah untuk mengedukasi masyarakat bagaimana cara mengelola sampah di Lingkungan Sayo Baru. Permasalahan sampah (khususnya sampah anorganik) sampai saat ini menjadi masalah yang sangat krusial di masyarakat. Jika permasalahan terkait sampah di lingkungan tersebut tidak segera ditangani, maka banjir yang kerap kali terjadi di beberapa tempat di lingkungan Sayo Baru tidak dapat teratasi, selain banjir sampah non organik yang berserakan juga mengurangi keindahan lingkungan Sayo Baru. Maka dari itu kami dari tim KKN Tematik Universitas Mataram mengajak masyarakat untuk lebih peduli lagi dalam hal bagaimana cara mengelola sampah non organik menjadi benda yang lebih bermanfaat. Dengan adanya program kerja ini, Mahasiswa KKN Tematik Universitas Mataram dapat membantu mengedukasi masyarakat tentang pentingnya mengelola sampah, mulai dari melakukan sosialisasi langsung di balai lingkungan dan pembagian brosur kepada masyarakat dan tentunya dapat mengurangi jumlah sampah harian di Lingkungan Sayo Baru, sehingga animo masyarakat untuk lebih peduli terhadap lingkungan dari sampah anorganik menjadi lebih tinggi. Adapun hasil dari kegiatan ini adalah terciptanya tempat sampah dari sampah non organik serta masyarakat sekitar merespon dengan baik karena mereka tidak bingung untuk membuang sampah rumahan yang ada.

Keywords: Anorganik; Botol Bekas; Zero Waste; Sampah Plastik; Ecobrick. 


\section{Pendahuluan}

Lingkungan sayo baru, Kelurahan Turida, Kecamatan Sandubaya, Kota Mataram merupakan salah satu lingkungan yang terletak di kompleks perumahan "Wisma Sweta Indah", perumahan Wisma Sweta Indah merupakan salah satu kompleks perumahan terbesar di Kota Mataram yang mencakup 2 lingkungan yaitu lingkungan Gegerung Indah dan Lingkungan Sayo Baru dari 5 lingkungan yang berada di Kelurahan Turida. Salah satu faktor permasalahan di lingkungan Sayo Baru adalah Banjir di beberapa RT di lingkungan tersebut yang disebabkan oleh tersumbatnya saluran pembuangan oleh sampah. Mengingat luas wilayah dan padatnya penduduk di lingkungan Sayo Baru menjadi salah satu faktor penyebab banyaknya sampah di lingkungan tersebut. Seperti kita ketahui, sebagian besar aktivitas manusia pada akhirnya menghasilkan sampah. Permasalahan sampah, khususnya sampah anorganik sampai saat ini menjadi masalah yang sangat krusial di masyarakat. Jika permasalahan terkait sampah di lingkungan tersebut tidak segera ditangani, maka banjir yang kerap kali terjadi di beberapa tempat di lingkungan Sayo Baru tersebut tidak dapat diatasi.

Dengan kondisi lingkungan yang luas dan padat penduduk, yang tentunya angka kebutuhan konsumtif di daerah tersebut menjadi lebih besar. Kebutuhan konsumtif ini tentu akan menghasilkan sampah, mengingat saat ini segala bentuk makanan dikemas rapi menggunakan bahan dasar plastik. Bungkus makanan yang sudah tidak terpakai tersebut yang akan menjadi sampah anorganik masyarakatdan hanya dilihat dari segi makanan, masih banyak kebutuhan lainnya yang dapat menghasilkan sampah anorganik, baik itu kebutuhan sandang dan papan.

Sampah anorganik ini sangat perlu dikelola karena sampah anorganik merupakan sampah yang sangat sulit terurai. Dari banyaknya jumlah penduduk lingkungan Sayo Baru yang dapat menghasilkan sampah anorganik lebih tinggi, seperti dipaparkan sebelumnya, mungkin penggunaan sampah anorganik akan sulit ditekan, tetapi hal yang perlu kita lakukan disini adalah bagaimana cara mengelola sampah anorganik tersebut menjadi sesuatu yang lebih bermanfaat untuk kehidupan. salah satu cara pengelolaan sampah menjadi lebih bermanfaat adalah dengan membuatnya menjadi "Ecobrick". Menurut
(Valentina.2018),Ecobrick berasal dari kata "Eco" dan "Brick" yang artinya bata ramah lingkungan. Disebut "bata" karena ia dapat menjadi alternatif bagi bata konvensional dalam mendirikan bangunan. Maka dari itu ecobrick biasa dimanfaatkan sebagai bahan baku pembuatan furniture. Ecobrick adalah botol plastik yang diisi padat dengan limbah non-biological untuk membuat blok bangunan yang dapat digunakan kembali (Ultimagsz, 2019). Eko-batu bata ini adalah teknologi berbasis kolaborasi yang menyediakan solusi limbah padat tanpa biaya untuk individu, rumah tangga, sekolah, masyarakat. Juga dikenal sebagai Bottle Brick atau Ecoladrillo. Solusi limbah lokal ini mulai disebut oleh masyarakat yang berkembang di seluruh dunia. Ecobrick adalah salah satu cara daur ulang sampah non organik secara sederhana, rendah biaya dan tidak memerlukan banyak tenaga kerja untuk menghasilkan berbagai macam manfaat bagi lingkungan (Himawati, 2015).

Tingkat konsumsi masyarakat yang meningkat menghasilkan buangan (limbah), salah satunya berupa limbah padat (sampah) (Dedi, Rezagama, \& Jatmiko, 2015). Selain itu, perkembangan teknologi juga berdampak pada banyaknya produksi jenis sampah (Solikhah, Hidayat, \& Ardian, 2016). Masalah sampah berkaitan erat dengan pola hidup serta budaya masyarakat itu sendiri. Penanganan sampah bukan hanya urusan pemerintah semata akan tetapi membutuhkan partisipasi masyarakat secara luas (Sahil, Henie, Al, Rohman, \& Syamsuri, 2016).

Penggunaan sampah plastik dalam kehidupan sehari-hari memang tidak bisa ditinggalkan, karena semua produk kebutuhan sehari-hari tidak terlepas dengan bungkus plastik/ botol. Sebagai salah satu solusi pemanfaatan sampah plastik, pembuatan ecobrick juga memiliki manfaat untuk mengurangi resiko bencana dan upaya konservasi sungai sebagai nadi kehidupan (Aryani, 2018). Penguraian sampah plastik secara alami membutuhkan waktu yang lama (Suminto, 2017)

Plastik terbuat dari zat-zat petrokimia. Zatzat kimia ini tidak layak kembali ke ekologi di sekitar kita. Penelitian ilmiah menunjukkan bahwa zat-zat kimia ini beracun bagi manusia. Plastik yang berceceran, dibakar, atau dibuang terurai menjadi zat-zat kimia beracun. Lambat laun, zatzat kimia ini larut ke tanah, air, dan udara, yang 
kemudian diserap oleh tumbuhan dan hewan. Pada akhirnya zat- zat itu akan menyebabkan cacat lahir, ketidakseimbangan hormon, dan kanker(Pavani \& Rajeswari,2014).

Salah satu sampah yang banyak menimbulkan masalah adalah sampah plastik. Plastik adalah salah satu jenis makromolekul yang dibentuk dengan proses polimerisasi. Polimerisasi adalah proses penggabungan beberapa molekul sederhana (monomer) melalui proses kimia menjadi molekul besar (makromolekul atau polimer). Plastik merupakan senyawa polimer yang unsur penyusun utamanya adalah Karbon dan Hidrogen. Untuk membuat plastik, salah satu bahan baku yang sering digunakan adalah Naphta, yaitu bahan yang dihasilkan dari penyulingan minyak bumi atau gas alam. Sebagai gambaran, untuk membuat $1 \mathrm{~kg}$ plastik memerlukan $1,75 \mathrm{~kg}$ minyak bumi , untuk memenuhi kebutuhan bahan bakunya maupun kebutuhan energi prosesnya (Kumar, dkk., 2011).

Penggunaan plastik dan barang-barang berbahan dasar plastik semakin meningkat seiring berkembangnya teknologi, industri dan juga jumlah populasi penduduk. Penggunaan bahan plastik semakin lama semakin meluas karena sifatnya kuat dan tidak mudah rusak oleh pelapukan. Diperkirakan sampah plastik yang ada di seluruh dunia mencapai 100 juta ton/tahun. Padahal plastik membutuhkan waktu 100 hingga 500 tahun untuk dapat terdekomposisi (terurai) dengan sempurna (Sahwan dkk, 2005).

Hal tersebut mengakibatkan keberadaan rekayasa TPST (Tempat Pembuangan Sampah Terakhir) menjadi solusi yang kurang baik dikarenakan terbatasnya lahan untuk menampung sampah. Selain itu, sampah-sampah yang menumpuk di TPS (Tempat Pembuangan Sampah) atau TPA (Tempat Pembuangan Akhir) secara tidak langsung juga dapat mempengaruhi kenaikan temperatur bumi di beberapa tempat. Hal tersebut memicu adanya pemanasan global yang terjadi akibat adanya peningkatan gas-gas rumah kaca seperti uap air, karbondioksida (CO2), metana (CH4). Gas metana $(\mathrm{CH} 4)$ dapat dirubah menjadi sumber energi yang akhirnya bisa bermanfaat bagi manusia. Sedangkan untuk gas karbondioksida (CO2), sampai saat ini belum ada pemanfaatan yang signifikan. Timbunan sampah di tempat pembuangan akhir yang terbuka bisa menimbulkan masalah yang lebih besar daripada yang dibanyangkan. Timbunan sampah yang dibiarkan dapat menyebarkan senyawa 2,2 bis (4hidroksifenil) propan atau dikenal sebagai Bisphenol-A (BPA) yang sangat berbahaya bagi tubuh. BPA ini merupakan bahan utama pada pembuatan plastik khususnya jenis polikarbonat. BPA yang masuk dalam tubuh dapat meniru aktivitas estrogen yang dapat mengakibatkan efek merugikan pada perkembangan organ dan sistem, termasuk sistem reproduksi, perkembangan otak, kelenjar susu dan sistem imun (Mujahiddin,2015).

Oleh karena itu, kami dari KKN Tematik unram mengadakan satu program kerja yang dapat mengajak masyarakat untuk bisa mengelola sampah menjadi benda yang lebih bermanfaat untuk kehidupan. Dalam hal ini kami memberikan edukasi dan memperkenalkan apa itu "Ecobrick" pada Masyarakat setempat. Dalam program kerja ini kami membuat tempat sampah dari sampah nonorganik untuk di sediakan di aula Lingkungan Sayo Baru

\section{Metode}

Kegiatan ini dilakukan di Kelurahan Turida, Kecamatan Sandubaya, Kota Mataram, tepatmya di Lingkungan Sayo Baru. Pelaksanaan kegiatan KKN dilaksanakan pada 11 Januari sampai dengan 25 Februari 2021, sedangkan untuk pelaksannaan Program Kerja "Ecobrick" ini dilaksanakan pada 12 Januari dan di rampungkan pada tanggal 13 Februari 2021 dengan sasaram warga masyarakat Lingkungan Sayo Baru.Solusi yang kami sampaikan ke masyarakat yaitu bagaimana cara menanggulangi sampah anorganik di lingkungan tersebut dengan cara mengubahnya menjadi sesuatu yang lebih bermanfaat.

Prosedur kegiatan : 1). Penyusunan Rencana, penyusunan rencana dilakukan dengan cara berdiskusi untuk melakukan kegiatan pembuatan ecobrick. 2). Persiapan, hal yang dipersiapkan adalah alat dan bahan seperti botol bekas, sampah non-organik, kawat, bambu, dan kantempat plastik. Alat dan bahan tersebut didapatkan dengan cara mengumpulkan dari milik warga yang sudah tak terpakai, khususnya sampah non-organik. 3). Pelaksanaan, pelaksanaan dimulai dari menggunting sampah non organik menjadi bagian kecil-kecil kemudian dimasukkan ke dalam botol plastik bekas sampai padat, hal ini dilakukan sampai mendapatkan kira-kira 80 botol. Lalu botol yang telah terisi sampah non organik dibentuk 
persegi dan dihubungkan atau diikat menggunakan kawat hingga membentuk kubus tanpa alas dan penutup, kemudian bagian bawah bentuk kubus yang disusun dari ecobrick tersebut ditutup menggunakan susunan bambu, setelah ecobrick dan bambu sudah terikat kuat dengan kawat jadilah tempat sampah dari ecobrick. Adapun cara sosialisasi dilakukan dengan lisan dan tulisan. Lisan dilakukan penjelasan di Balai Lingkungan, sedangkan tulisan dengan cara pembuatan brosur.

\section{Hasil dan Pembahasan}

Program kerja ini menghasilkan sebuah tempat sampah yang terbuat dari sampah non organik yang dibentuk menjadi ecobrick, serta berhasil memanfaatkan sampah-sampah non organik di Lingkungan Sayo Baru untuk diolah menjadi barang yang lebih bermanfaat, dampak lain adalah populasi sampah non organik menjadi lebih terkendali. Pada dasarnya kegiatan membuat ecobrick tidak terbatas hanya pada pembuatan tempat sampah saja, tetapi bisa membuat benda lain seperti kursi, meja, pot dan lainnya berdasarkan kebutuhan dan kreativitas.

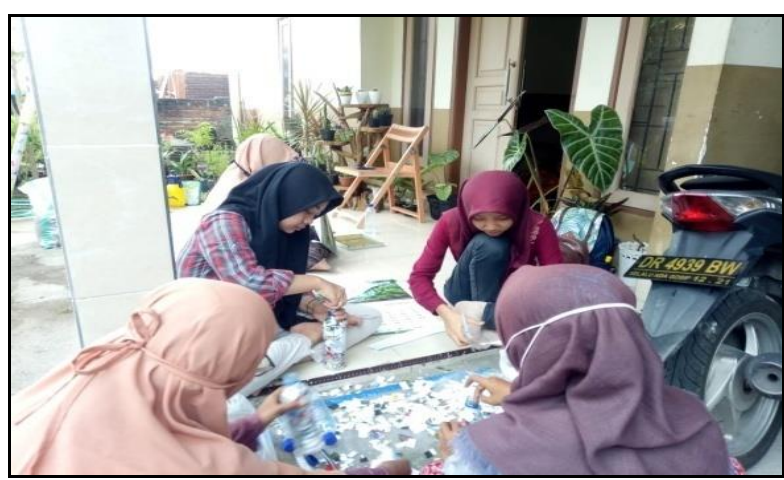

Gambar 1. Pengerjaan ecobrick bersama dengan tim inti KKN.

Pelaksanaan, pelaksanaan dimulai dari menggunting sampah non organik menjadi bagian kecil-kecil kemudian dimasukkan ke dalam botol plastik bekas sampai padat, hal ini dilakukan sampai mendapatkan kira-kira 80 botol. Lalu botol yang telah terisi sampah non organik dibentuk persegi dan dihubungkan atau diikat menggunakan kawat hingga membentuk kubus tanpa alas dan penutup, kemudian bagian bawah bentuk kubus yang disusun dari ecobrick tersebut ditutup menggunakan susunan bambu, setelah ecobrick dan bambu sudah terikat kuat dengan kawat jadilah tempat sampah dari ecobrick.

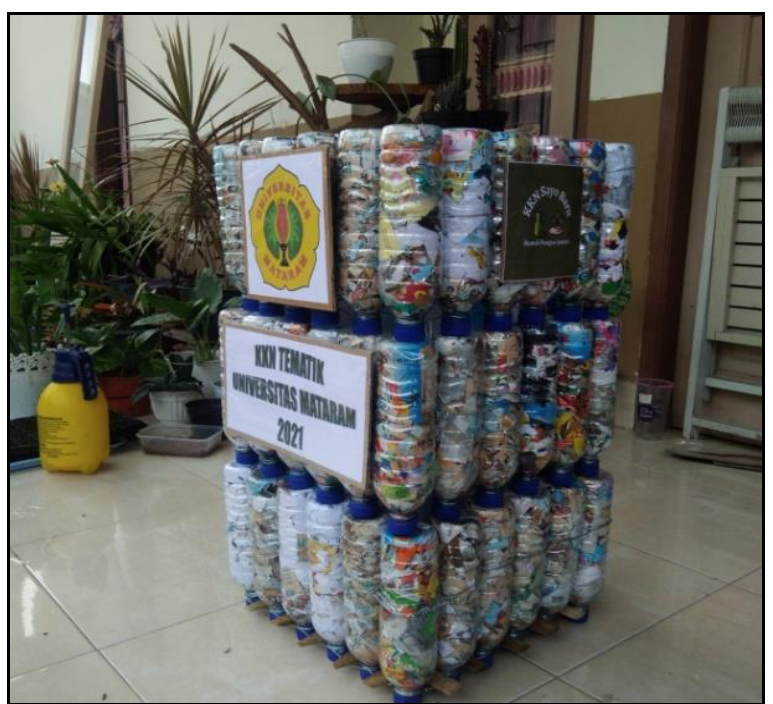

Gambar2. Tempat sampah ecobrick.

Hasil dari program kegiatan Ecobrick adalah terciptanya tempat sampah dari sampah non organik seperti gambar serta solusi dari sampah non organik di lingkungan Sayo Baru.

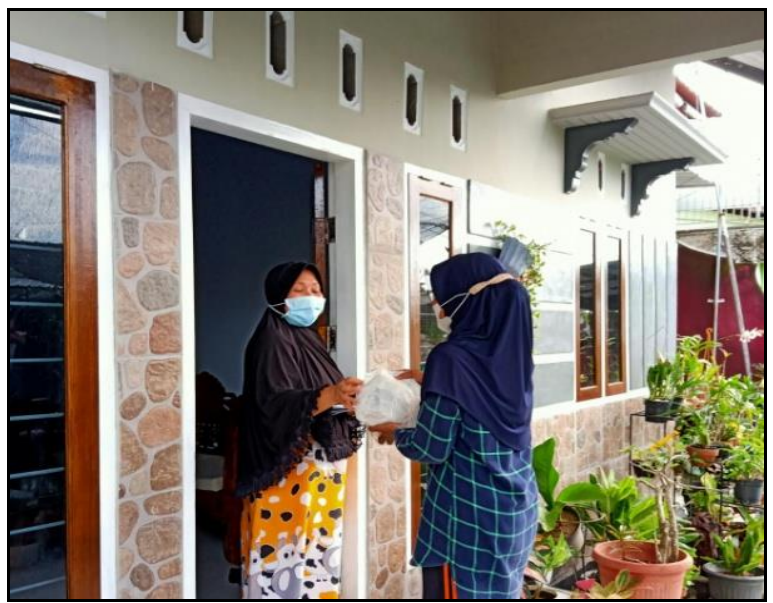

Gambar 3. Pengambilan Sampah anorgamik dari warga Lingkungan Sayo Baru

Kegiatan pengumpulan sampah non organik dari warga lingkungan Sayo Baru untuk membuat ecobrick berupa tempat sampah sekaligus menjelaskan maksud tujuan KKN, Ecobrick secara singat dan sederhana dan mudah dimengerti oleh warga Lingkungan Sayo Baru. 


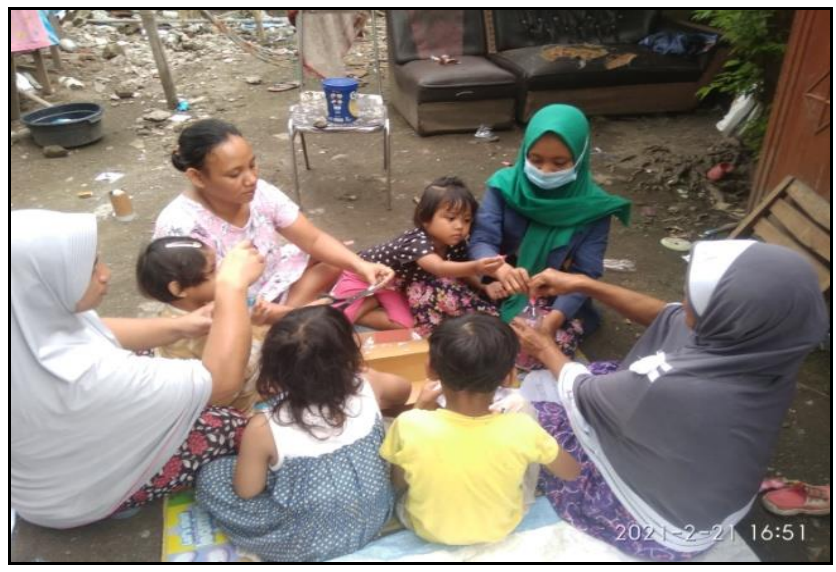

Gambar 4. Pengerjaan ecobrick sekaligus mengedukasi masyarakatdananak-anak sekitarlokasi KKN.

Pengerjaan ecobrick bersama warga sekaligus edukasi mengenai ecobrick baik dari segi tujuan, mafaat, cara pembuatan. Salah satu faktor permasalahan di lingkungan Sayo Baru adalah Banjir di beberapa RT di lingkungan tersebut yang disebabkan oleh tersumbatnya saluran pembuangan oleh sampah. Mengingat luas wilayah dan padatnya penduduk di lingkungan Sayo Baru menjadi salah satu faktor penyebab banyaknya sampah di lingkungan tersebut. Seperti kita ketahui, sebagian besar aktivitas manusia pada akhirnya menghasilkan sampah. Permasalahan sampah (khususnya sampah anorganik) sampai saat ini menjadi masalah yang sangat krusial di masyarakat. Jika permasalahan terkait sampah di lingkungan tersebut tidak segera ditangani, maka banjir yang kerap kali terjadi di beberapa tempat di lingkungan Sayo Baru tersebut tidak dapat diatasi serta pencemaran tanah yang terjadi di lingkungan Sayo Baru akibat sampah non organik yang tidak ditangani kemudian tertimbun dalam tanah dengan kurun waktu yang lama dapat menyebabkan pencemaran pada tanah. Untuk dapat menyelesaikan masalah sampah anorganik tersebut kami dari tim KKN Tematik Universitas Mataram mengadakan sebuah program kerja agar bagaimana menanggulangi banyaknya populasi sampah anorganik tersebut sekaligus bersama sama mengajak masyarakat setempat untuk mendukung program kerja kami tersebut. Program kerja yang dimaksud adalah program kerja merubah sampahsampah anorganik tersebut menjadi ecobrick. Ecobrick adalah cara daur ulang sampah plastik secara sederhana dan ini terbukti mengurangi sampah non organik karena sampah non organik yang ada bisa diolah langsung tanpa harus ditumpuk lama dan menyebabkan masalah seperti banjir dan pencemaran tanah. Cara membuat tempat sampah ecobrick dilakukan dengan cara sampah plastik yang diisi ke dalam botol plastik sampai padat, kemudian botol plastik yang sudah padat tersebut dapat disusun menjadi berbagai macam benda yang dapat dimanfaatkan untuk kebutuhan sehari-hari, seperti program kerja kami ini, botolbotol ecobrick yang telah kami buat kami susun menjadi sebuah tempat sampah yang dapat digunakan untuk kebutuhan bersama (Umum), karena tempat sampah yang telah kami buat tersebut di serahkan di aula Lingkungan Sayo Baru, yang berhadapan langsung dengan lapangan umum untuk masyarakat Lingkungan Sayo Baru.

Kendala yang kami hadapi dalam pengerjaan ecobrick ini yaitu diperlukan waktu yang cukup banyak, sehingga kami juga mengerjakannya di luar jam kerja, mengingat waktu KKN kami hanya sampai 45 hari dan target kami, tempat sampah ecobrick ini harus sudah rampung sebelum Penarikan KKN. semoga kedepannya kami masih diberikan kesehatan untuk bisa berkontribusi kembali meskipun di luar KKN untuk masyarakat Lingkungan Sayo Baru, sehingga bukan hanya tempat sampah yang bisa dibuat, tetapi benda benda lain yang bisa bermanfaat untuk kebutuhan bersama dan tentunya dengan kegiatan ini populasi sampah menjadi berkurang sehingga Lingkungan lebih bersih, sehat dan terhindar dari bencana banjir.

\section{Kesimpulan}

Untuk dapat menyelesaikan masalah sampah anorganik di Lingkungan Sayo Baru, kami dari tim KKN Tematik Universitas Mataram mengadakan sebuah program kerja agar bagaimana cara menanggulangi banyaknya populasi sampah anorganik tersebut sekaligus bersama sama mengajak masyarakat setempat untuk mendukung program kerja kami tersebut. Program kerja yang dimaksud adalah program kerja merubah sampahsampah anorganik tersebut menjadi ecobrick. Ecobrick adalah sampah plastik yang diisi ke dalam botol plastik sampai padat, kemudian botol plastik yang sudah padat tersebut dapat disusun menjadi berbagai macam benda yang dapat dimanfaatkan untuk kebutuhan sehari-hari, seperti program kerja kami ini, botol-botol ecobrick yang telah kami buat kami susun menjadi sebuah tempat sampah yang 
dapat digunakan untuk kebutuhan bersama (Umum).

\section{Daftar Pustaka}

Dedi, D., Rezagama, A., \& Jatmiko, A. (2015), Analisis Ekonomi Lingkungan Terhadap Tempat Pemrosesan Akhir Sampah (TPA) Jatibarang Kota Semarang, Jurnal Teknik Lingkungan.

Himawati, A. (2015) Meng_Ecobrick di Rumah Sendiri. Yogyakarta : Penerbit Kendi Aksara

Kumar S., Panda, A.K., dan Singh, R.K. (2011) A Review on Tertiary Recycling of HighDensity Polyethylene to Fuel, Resources, Conservation and Recycling Vol. 55 893910.

Mujahiddin. 2015. Faktor-Faktor yang Mempengaruhi Upaya Pemberdayaan Masyarakat dalam Mengelola Sampah Anorganik di Bank Sampah Simpan Jadi Mas. Jurnal Keskap Fisip, 13(1): 305-331.

Pavani, P., \& Rajeswari, T. R. (n.d.). National Seminar on Impact of Toxic Metals, Minerals and Solvents leading to Environmental Pollution-2014 Journal of Chemical and Pharmaceutical Sciences IMPACT OF PLASTICS ON ENVIRONMENTAL POLLUTION. Retrieved from www.jchps.com

Sahil, J., Henie, M., Al, I., Rohman, F., \& Syamsuri, I. (2016). Sistem Pengelolaan dan Upaya Penanggulangan Sampah Di Kelurahan Dufa- Dufa Kota Ternate. BIOeduKASI, 4(2), 478-487.

Sahwan, F.L., Martono, D.H., Wahyono, S., Wisoyodharmo, L.A. (2005) Sistem Pengolahan Limbah Plastik di Indonesia, Jurnal Teknik Lingkungan BPPT 6 (1), halaman $311-318$.

Solikhah, N. H., Hidayat, A. S., \& Ardian, A. A. N. (2016). Dampak Keberadaan Tempat Pembuangan Akhir (TPA) terhadap Kondisi Sosial Masyarakat Dusun Ngablak, Desa Sitimulyo, Kecamatan Piyungan, Kabupaten Bantul, 1-8.
Suminto, S. (2017). Ecobrick : Solusi Cerdas dan Kreatif untuk Mengatasi Sampah Plastik, 3(1),26-35. 